\title{
骨芽細胞様細胞の培養ステージによるチタンプレートへの細胞付着の変化
}

\author{
光 本 和世
}

\section{Changes in the attachment of osteoblastic cells to titanium plates at the different stages of culture}

\author{
Kazuyo Miтsumoto
}

\begin{abstract}
It is widely accepted that the ability of osteoblastic cells to attach to titanium plates is influenced by many factors. In this study, the author examined whether the initial attachment of osteoblastic cells (MC 3 T 3 -E 1 cells) to titanium plates was affected by the stage of cell differentiation and by pretreatment with transforming growth factor- $\beta$ (TGF- $\beta$ ).

The cells were divided into four groups according to the stage of culture: stage I (proliferating stage), stage II (preconfluent stage), stage III (confluent stage), and stage IV (nodule-forming stage). Cell attachment was then estimated by crystal violet staining.

The results revealed that cell attachment increased with the advancement of stage. At the final stage (stage IV), however, cell attachment decreased. TGF- $\beta$ increased cell attachment through de novo protein synthesis. When the effect of TGF- $\beta$ was compared between stage II and stage III, the cells at stage II were more responsive to TGF- $\beta$ than those at stage III. These results suggest that the affinity of MC $3 \mathrm{~T} 3-\mathrm{E} 1$ cells to titanium plates may differ according to the stage of differentiation and that this affinity may be modulated by TGF- $\beta$.
\end{abstract}

Key words: osteoblastic cell (骨芽細胞様細胞), titanium plate (チタンプレート), cell attachment (細胞付着), cell differentiation (細胞分化), TGF- $\beta$ (TGF- $\beta$ )

緒

言

生体材料を患者に使用する際, 材料の性質, 形状, あるいは生体への為害性を考慮することは当然のこと であるが, 生体側の要因も考えなければならない. 実 際に, 患者の年齢や使用部位によって生体材料の適合 状態が異なることは日頃経験されるところである。

近年, 骨組織中に分化状態の異なる複数の骨芽細胞 群が存在することが明らかになってきた $\left.{ }^{2}, 2\right)$.また水 野ら $\left.{ }^{3}\right)$ は, マウス頭蓋骨由来の MC 3 T 3-E 1 細胞を 培養し, 骨芽細胞の分化マーカーの発現と培養状態と

昭和大学歯学部第二口腔外科学教室

(主任 : 南雲正男教授)

Second Department of Oral and Maxillofacial Surgery, School of Dentistry, Showa University (Chief: Prof. Masao Nagumo)

受付日 : 平成 7 年 12 月 20 日
の関連を検討した. その結果, 培養ステージによって それらの発現が異なり, 分化状態の異なる骨芽細胞様 細胞が培養日数の経過とともに出現することを報告し ている.これらの所見は, 患者の年齢や部位によって 骨芽細胞の状態や性状が異なる可能性があることを意 味するものと考えられる。

一方, 骨組織中には各種のサイトカインが存在し, これらが骨芽細胞の機能を調節しているといわれてい る4).このうち Transforming growth factor- $\beta$ (TGF- $\beta$ ) は成長因子の 1 つとして知られ, 骨基質内 に多量に存在する ${ }^{4)}$.このサイトカインは, 骨組織由 来の細胞であっても細胞によりその作用が異なること が知られている4，5).したがって，培養ステージの異 なる細胞の生体材料の組織適合性に対して, TGF- $\beta$ がどのような効果をもつのか検討することは, 生体材 料の臨床応用を考える上で興味深い.

当教室では生体適合性の良いチタンプレートの開発 
を目指し, in vitroの系で骨芽細胞様細胞の適合性に ついて検討してきた. その結果, 細胞はチタンプレー トに早期に付着すること，そしてチタンプレート表面 の性状により細胞付着率が異なることを明らかにし た6). そこで今回は, MC 3 T 3-E 1 細胞を培養し, 培 養ステージの異なる細胞を採取し，これらの細胞群の 間でチタンプレートへの初期付着に違いがみられるか いなかを検討した，さらに，培養ステージの異なる細 胞群にTGF- $\beta$ を作用させた後細胞を採取し，TGF$\beta$ 処理によりプレートへの細胞付着がどのように変化 するかをあわせて検討した。

\section{実 験 方 法}

\section{1. 実験材料と細胞の調製}

骨芽細胞様細胞としては, Kodama ら 7，8) が樹立 したマウス頭蓋骨由来の MC 3 T 3-E 1 細胞を, $10 \%$ FBS (胎児牛血清; Gibco 社製) を含む $\alpha-M E M$ (Gibco 社製) で継代して使用した.チタンプレート は昭和大学歯学部歯科理工学教室にて作成した $10 \times$ $10 \times 1 \mathrm{~mm}$ の比較的表面が平滑な（凹凸 $3 \mu \mathrm{m}$ 以内） プレートを使用した ${ }^{9,10)}$.

\section{2 . 細胞付着の評価}

まず，チタンプレートを $10 \% \mathrm{FBS}-\alpha-\mathrm{MEM} に$ に浸し， 30 分間 $\mathrm{CO}_{2}$ インキュベーター内で前処理した。つい で, チタンプレートを 24 穴マルチプルウェルプレー ト (Corning 社製) のウェルに入れ, 各ウェルに $\alpha-$ MEM で一定数の細胞数に調整した細胞浮遊液 $1 \mathrm{ml}$ を加え，2 時間 $\mathrm{CO}_{2}$ インキュベータ内に静置した。 そ の後, チタンプレートを $2 \mathrm{ml}$ のリン酸緩衝液 (PBS) で 2 回洗浄して非付着細胞を除去した後, 新しい 24 穴マルチプルウェルプレートのウェル内にチタンプレー トを移して細胞付着を評価した，細胞付着の評価は， Zacharchuk らの方法11) に準じて行った。すなわち， チタンプレートを $2 \%$ エ ーノルに溶解した $0.2 \%$ ク リスタルバイオレット (和光純薬) $0.5 \mathrm{ml}$ で覆って 30 分間放置した後, 過剩のクリスタルバイオレットを PBS にて洗浄除去 ( $2 \mathrm{ml} /$ ウル 5 回) した. その後, $1 \%$ ドデシル硫酸ナトリウム (SDS , 和光純薬) 溶液 を $1 \mathrm{ml}$ 加えて軽く振動しながら室温に 1 時間放置し, 細胞を染めたクリスタルバイオレットを溶解し， 540nm にて吸光度を測定して細胞付着を評価した.

\section{3 . TGF- $\beta$ の効果の検討}

$1 \times 10^{5} / 4 \mathrm{ml}$ に調製した MC 3 T 3 - E 1 細胞を底 面積 $25 \mathrm{~cm}^{2}$ のフラスコ（Falcon 社製）にまき，培養 液を 2 日おきに交換し, サブコンフルエントになった 細胞に TGF- $\beta$ を添加してその効果を検討した. すな わち, 細胞を $\alpha$-MEM で洗浄した後, $2 \%$ FBS- $\alpha$ MEM を加えて各種濃度の TGF- $\beta$ （宝酒造株式会社） を添加した. 24 時間および 48 時間後 $0.25 \%$ trypsin-

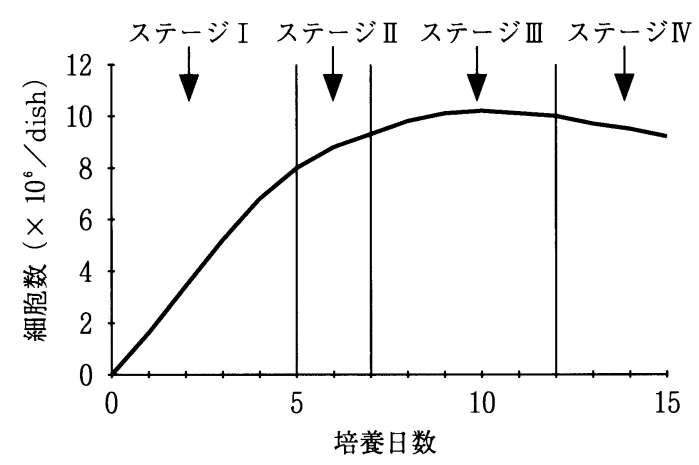

図 1 培養日数による細胞数の変化

0.02\%EDTA（共に sigma 社製）処理により細胞を回 収し， $\alpha$-MEM で細胞を懸濁してチタンプレート上に まいて細胞付着を検討した. また, TGF- $\beta$ の作用が蛋 白合成を介しているかどうかを確認するため，一部の 実験では TGF- $\beta$ とともにシクロフォスアミド (sigma 社製) を添加した。

\section{4. 細胞の培養ステージによる反応性の变化}

$1 \times 10^{5} / \mathrm{ml}$ の細胞を底面積 $25 \mathrm{~cm}^{2}$ のフラスコに まき, 経時的に $0.25 \%$ trypsin-0.02\%EDTA 処理して 細胞を剥し, 細胞数をカウントして増殖曲線を作成し た（図 1). 増殖曲線から細胞の状態をステージ I（増 殖期), ステージII (コンフルエント直前の時期), ス テージIII (コンフルエントの時期), ステージIV（結節 を形成し始める時期) に分けて，それぞれのステージ の細胞を回収し, 細胞のチタンプレートへの付着を検 討した. また, ステージII および吕については TGF$\beta$ を添加し, 細胞付着におよぼす TGF- $\beta$ の効果につ いてあわせて検討した。

なお, 結果については $\mathrm{t}$ 検定処理を行い有意差を検 定した.

\section{結果}

\section{1. クリスタルバイオレットによる細胞付着の評価}

サブコンフルエントの MC $3 \mathrm{~T} 3-\mathrm{E}_{1}$ 細胞のチタン プレートへの付着を, 反応時間を 1 時間から 6 時間と 変えて検討したところ, 培養時間とともに細胞付着が 増加した (図 2 -a). また, 反応時間を一定 (2 時間) にして細胞数を $1 \times 10^{5} / \mathrm{ml}, 2 \times 10^{5} / \mathrm{ml}, 4 \times 10^{5}$ $/ \mathrm{ml}$ と変えて検討したところ, 細胞数の増加ととも に細胞付着が増加した (図 2-b). そこで, 以下の実験 では反応時間を 2 時間とし, プレートあたり $1 \times 10^{5}$ $/ \mathrm{ml}$ から $2 \times 10^{5} / \mathrm{ml}$ の細胞数を用いて行った.

\section{2. 細胞の培養ステージによる細胞付着の変化}

各ステージの細胞を採取してチタンプレートへの細 胞付着について検討した. その結果, ステージが I か 

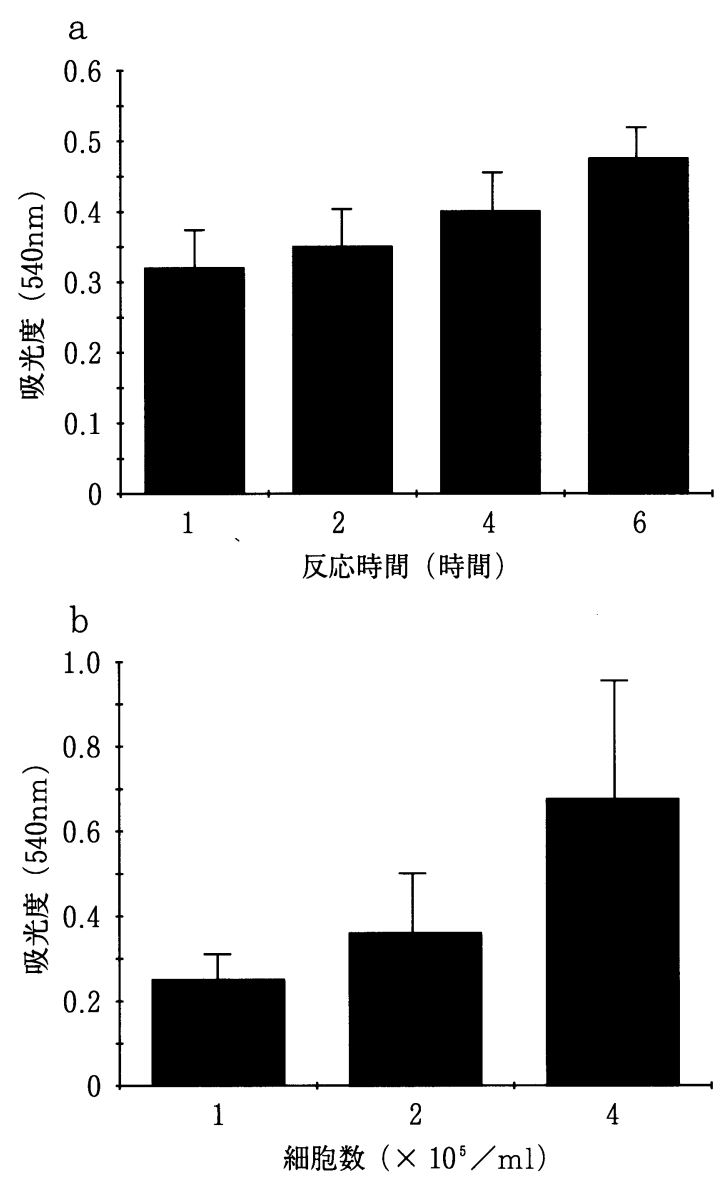

図 2 a. 反応時間による細胞付着の変化. 細胞数は $2 \times$ $10^{5} /$ ウル $/ 1 \mathrm{ml}$. 実験は $\mathrm{n}=5$, 結果は Mean \pm SD.

b. 細胞数による細胞付着の変化. プレートへの付 着時間は 2 時間. 実験は $\mathrm{n}=5$, 結果は Mean $\pm \mathrm{SD}$.

ら III と進むにつれて細胞付着が増加した．しかし，ス テージIVになると細胞付着は減少した（図 3 ).

\section{3 . TGF- $\beta$ の効果}

$500 \mathrm{pg} / \mathrm{ml}$ および $5000 \mathrm{pg} / \mathrm{ml}$ の濃度の TGF- $\beta$ を それぞれ 24 時間および 48 時間作用させた後 MC 3 T 3 E 1 細胞を回収し,チタンプレートへの細胞付着を検 討した. 24 時間作用させた場合には明らかな TGF- $\beta$ の効果はみられなかったが (図 4 -a)，48 時間作用さ せた細胞においては濃度依存的にチタンプレートへの 細胞付着が増加した (図 4-b). とくに5000pg / ml で は, 24 時間作用させた場合に比べて有意な増加を示し た.このチタンプレートへの細胞付着の増加は, シク ロホスファミドを作用させると濃度依存的に抑制され た (図 5 ).

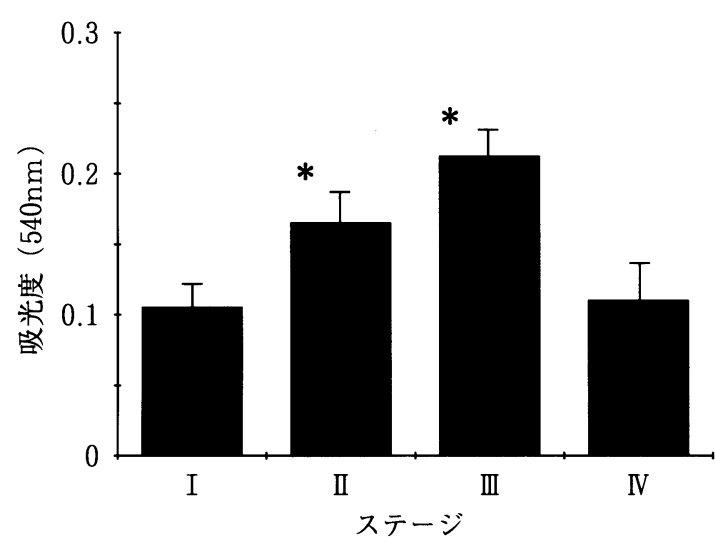

図 3 MC 3 T 3-E 1 細胞の各培養ステージにおける細 胞付着. 細胞数は $1 \times 10^{5} /$ ウル $/ 1 \mathrm{ml}$, プレート への付着時間は 2 時間. 実験は $\mathrm{n}=5$, 結果は Mean $\pm \mathrm{SD} . * \mathrm{P}<0.05$ (ステージ Iに対して)

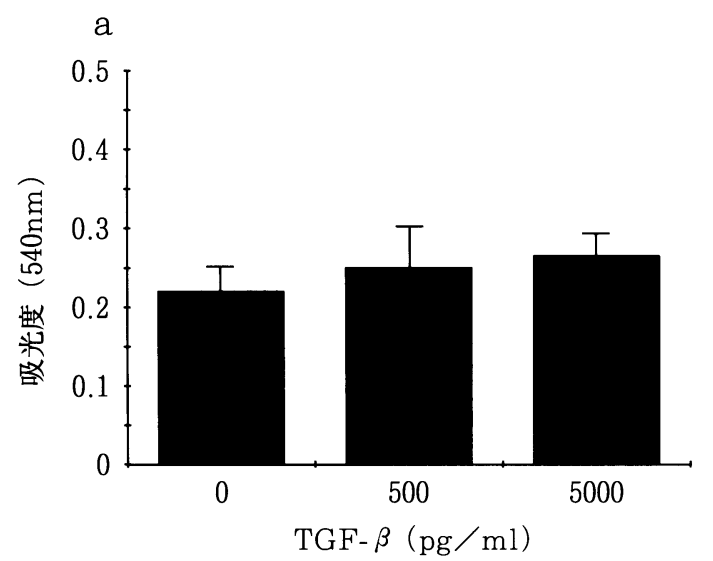

$\mathrm{b}$

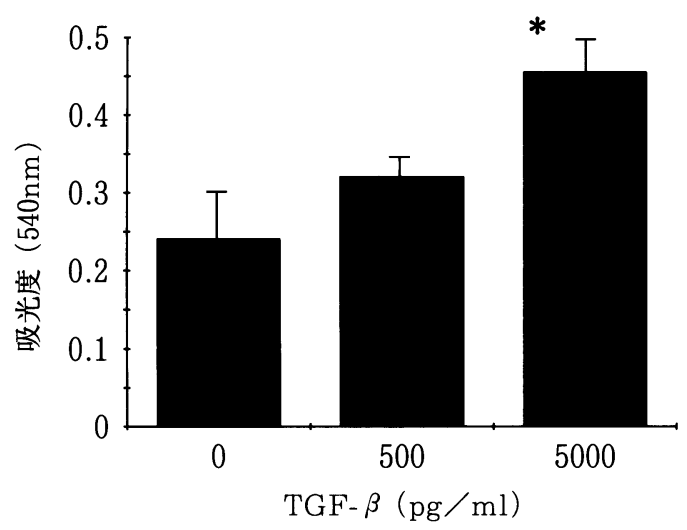

図 $4 \mathrm{TGF}-\beta$ の細胞付着に対する効果. 細胞数は $1 \times$ $10^{5} /$ ウェル $/ 1 \mathrm{ml}$.

a. TGF- $\beta$ を 24 時間作用させた後の細胞付着.

b. TGF- $\beta$ を 48 時間作用させた後の細胞付着. プレート への付着時間は 2 時間. 実験は $\mathrm{n}=5$, 結果は Mean \pm SD. * P $<0.01$ (TGF- $\beta$ 無添加に対して) 


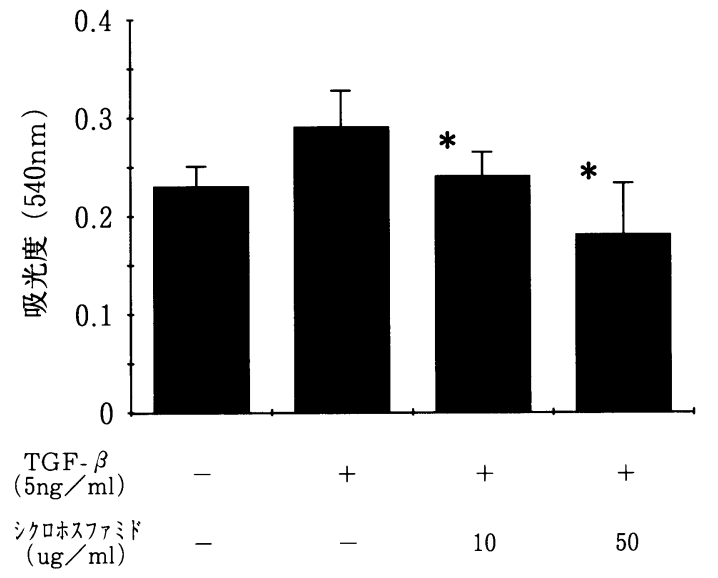

図 5 シクロフォスファミドの効果. TGF- $\beta$ と同時に 48 時間シクロフォスファミドを添加. 細胞数は $1 \times$ $10^{5} /$ ウル $/ 1 \mathrm{ml}$, プレートへの付着時間は 2 時 間. 実験は $\mathrm{n}=4$, 結果は Mean $\pm \mathrm{SD}$. * $\mathrm{P}<0.01$ $[\mathrm{TGF}-\beta 5000 \mathrm{pg} / \mathrm{ml}$, シクロフォスファミド $(-)$ に対して]

次に細胞の培養ステージで TGF- $\beta$ の効果が異なる かいなかを検討した. ステージIIのコンフルエント直 前の時期では TGF- $\beta$ を作用させると細胞付着能が増 加したが，ステージ而のコンフルエントの時期ではこ のような効果はみられなかった（図6）.また，ステー ジIVでもステージ III同様に TGF- $\beta$ の効果はみられな かった. なお, ステージIについては細胞は増殖期に あり, TGF- $\beta$ の効果を検討するには細胞の収集率が 悪く, かつ結果も一定でなかったので割愛した。

\section{考察}

近年チタン材料は生体為害性がなく，適合性が良い ことから人工歯根材料, 骨接合材, および顎骨補填材 として高頻度に使用されている。しかし，症例によっ ては動摇あるいは感染などをきたし，埋入したものを 除去しなければならないことがある. 生体為害性がな く, 適合性が良いにもかかわらず, 満足な結果が得ら れない原因のひとつとして, 材料を受け入れる生体側 に対する評価が十分になされていないことがあげられ る. Chang ら ${ }^{12)}$ は, 脱灰骨を年歯の異なるラットに移 植して骨誘導能を検討したところ, 老㱓化した動物で は著しく骨誘導能が低下していることを明らかにした. さらに代田ら 13）も，加齢によりヒドロキシアパタイト と骨の結合が低下することを報告している。これらの 結果は, 骨組織に存在する骨芽細胞の機能が加齢によ り変化し, 骨形成能および結合能が低下したことによ るものと推測される.山口 ${ }^{1,2)}$ は, 骨組織に分化状態 が異なる多くの種類の骨芽細胞様細胞が存在すると述

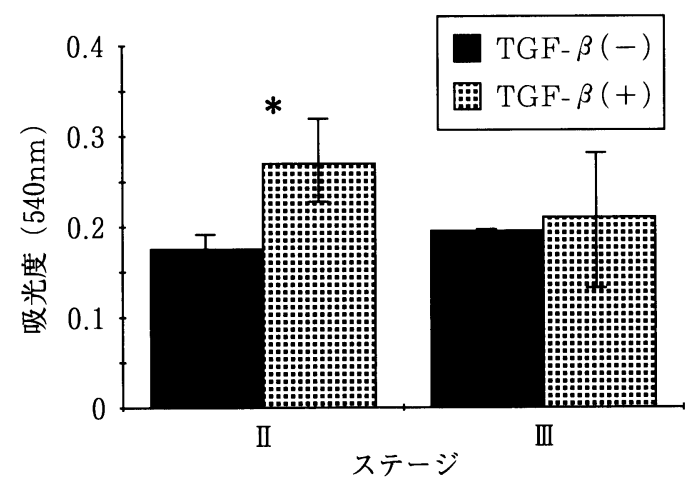

図 6 ステージII およびステージIII の細胞に対するTGF$\beta$ の効果. 細胞数は $1 \times 10^{5} /$ ウル $/ 1 \mathrm{ml}$ で TGF$\beta 2000 \mathrm{pg} / \mathrm{ml}$ を 48 時間作用させた. プレートへの 付着時間は 2 時間. 実験は $\mathrm{n}=6$, 結果は Mean \pm $\mathrm{SD} . * \mathrm{P}<0.05$ (TGF- $\beta$ 無添加に対して)

べている.さらに腰原ら ${ }^{14)}$ は, 外科処置時に採取した 各種年齢層の骨組織から骨芽細胞様細胞を分離し, 骨 芽細胞としての分化マーカーを検索したところ, 年齢 層によりマーカーの反応性が異なることを示した。さ らに角田らも ${ }^{15)}$, 複数の骨芽細胞様細胞を用いて放射 線の感受性を検討し, 細胞の種類により感受性が異な ることを報告している．したがって，チタンの臨床応 用を考える上で分化状態の異なる骨芽細胞様細胞とチ タンプレートとの適合性を検討することは重要である と思われる。

MC 3 T 3 -E 1 細胞は, マウス頭蓋骨より分離され, 培養を続けていくと骨芽細胞としての形質を発現する 細胞株である ${ }^{7)}$. この細胞はコンフルエントに達する とコラーゲンやプロテオグリカンなどの骨基質を合成 するとともに,アルカリフォスファターゼ (AL-pase) 活性を発現するようになる．MC 3 T 3-E 1 細胞の AL-pase 活性は, 培養日数の経過とともに上昇し, プ ラトーに達すると細胞周辺に石灰化がみられるように なり, 最終的には骨組織が形成される ${ }^{8)}$. そのほかの 骨芽細胞としての分化マーカーの発現もステージによ り異なることが報告されている ${ }^{3)}$. そこで著者は， MC 3 T 3-E 1 細胞の培養ステージを 4 段階に分けて 細胞を集め, チタンプレートへの付着能を検討した。 その結果, ステージIおよびステージ吕において他の ステージに比較して高い付着能を有することが判明し た.これらの時期は, それぞれ AL-pase 活性の発現が 認められる前の時期 (ステージII) とその活性が発現 し, 次第に上昇していく時期（ステージ血）に相当す る. 一方, 細胞分裂の盛んな時期（ステージI）およ び結節が形成され石灰化が開始する時期 (ステージIV) の細胞は, プレートへの付着能が低いことが示された. これらの結果は, 骨芽細胞の分化状態によりチタンプ 
レートへの細胞付着能が異なることを示唆しているも のと考えられる.

骨基質内に多量に存在する TGF- $\beta$ は，骨代謝にお ける局所の骨形成調節因子として注目されているサイ トカインのひとつである。このサイトカインを in vivo で幼若動物に局所投与すると骨形成を促進する との報告があるが16,17)，逆に骨吸収にも関与している との報告 ${ }^{18 ） も あ る . ~ そ こ て ゙, ~ T B F-~} \beta$ を骨芽細胞様細 胞に作用させ, 細胞付着がどのように変化するかを検 討した. その結果, 48 時間 TGF- $\beta$ を細胞に作用させ たところ, 濃度依存的にチタンプレートへの細胞付着 能が上昇した.この TGF- $\beta$ の効果は, シクロホスファ ミドにより完全に消失した.このことより, TGF- $\beta$ に よる細胞付着能の増強には de novoの蛋白合成が必 要であること,そのためには 24 時間以上の時間が必 要とされることが推察された.この蛋白がどのような ものであるのかは今回の研究からは不明であるが, お そらくチタンプレートへの細胞付着に関与しているも のと考えられる.

次に細胞の培養ステージにより, TGF- $\beta$ への反応 性に違いがみられるかいなかを検討した，その結果， ステージII のコンフルエント直前の細胞は, TGF- $\beta$ に反応して細胞付着能が上昇した.この結果は, 培養 ステージによって細胞の TGF- $\beta$ への反応性が異なる ことを示している. 何故コンフルエント直前の細胞が TGF- $\beta$ に反応を示し, コンフルエントになると反応 を示さなくなるかについては今回の実験からは明らか でない. 竹内ら ${ }^{19)}$ は, MC 3 T 3-E 1 細胞の分化と TGF- $\beta$ の作用との関係について検討し, 培養 1 週目 すなわち AL-pase が上昇する前のステージの細胞で は TGF- $\beta$ に反応してプロテオグリカンの合成が促進 するが, AL-pase 活性が上昇する時期ではその反応性 がほとんどみられないことを明らかにした，そこで， TGF- $\beta$ の受容体を検討したところ, 培養初期では $\mathrm{MC} 3 \mathrm{~T} 3-\mathrm{E}_{1}$ 細胞の細胞膜に TGF- $\beta$ の受容体が発現 しているが, 培養 2 週目に入るとそれが著明に減少す ることを示した．本研究でも AL-pase 活性が上昇す るステージでは, TGF- $\beta$ の効果がみられなかった. し たがって, ステージ四すなわちコンフルエントの状態 の細胞で TGF- $\beta$ 処理によりチタンプレートへの細胞 付着の増加がみられなかったのは, TGF- $\beta$ の受容体 が減少したことによって TGF- $\beta$ の反応性が低下した ことによると推測されるが, これについては今後検討 の必要がある。

近年, 高齢化社会を迎えて骨粗棌症患者数が増加し ている.これらの患者では骨形成の低下がみられるが, その理由として加齢に伴う骨成長因子の合成の低下， あるいは成長因子に対する骨芽細胞の反応性の低下， さらに骨基質蛋白の合成の低下が関与している可能性 が示唆されている ${ }^{12,20)}$. このことと本研究の結果を考
え合わせると, 今後生体材料の適合性を検討する際に は, 使用される生体側の条件を考慮して行うことが重 要になってくるものと考えられる.

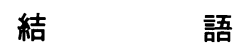

骨芽細胞様細胞である $\mathrm{MC} 3 \mathrm{~T} 3-\mathrm{E}_{1}$ 細胞の培養ス テージの違いによるチタンプレートへの初期付着の変 化と細胞付着に対する TGF- $\beta$ の効果について検討し た. その結果, 次のような所見が得られた.

1. MC 3T 3-E 1 細胞のチタンプレートへの付着は 培養時間とともに, また細胞数が増すとともに増加し た。

2. MC 3 T 3 -E 1 細胞の培養ステージをステージ I (増殖期), ステージII（コンフルエント直前の時期), ステージIII (コンフルエントの時期), ステージIV（結 節を形成し始める時期）に分けてチタンプレートへの 細胞付着能を検討したところ, 細胞付着能はステージ が I から血に進むにつれて上昇したが, ステージ VV なると逆に低下した。

3. TGF- $\beta$ をサブコンフルエントの MC 3 T 3 -E 1 細胞に作用させたところ, 24 時間では明らかな効果は 見られなかったが, 48 時間作用させた細胞ではチタン プレートへの細胞付着能が濃度依存的に上昇した。

4. TGF- $\beta$ 効果による細胞付着能の上昇は, シクロ ホスファミドを作用させると完全に抑制された。

5 . 細胞の各培養ステージで TGF- $\beta$ の効果を検討 したところ, ステージIIでは TGF- $\beta$ の効果が認めら れたが, ステージ血ではほとんど効果はみられなかっ た。

以上の結果から，骨芽細胞様細胞の培養ステージに よりチタンプレートへの細胞の初期付着能に違いがあ ること,および細胞に TGF- $\beta$ を作用をさせると細胞 付着能が上昇することが明らかになった，さらに，細 胞の培養ステージにより TGF- $\beta$ の効果が異なること が判明した.

\section{謝辞}

稿を終えるにあたり,ご指導および御校閲を賜った昭 和大学歯学部第二口腔外科学教室南雲正男教授に深甚の 謝意を表します.またご指導いただいた角田左武郎助教 授ならびに第二口腔外科学教室各位に心よりお礼申し上 げます。

\section{引用文 献}

1）山口 朗：骨芽細胞の起源と分化. BIOmedica 8:23-27 1993.

2) Yamaguchi, A., Kahn, A.J.: Clonal osteogenic cell lines express myogenic and adipocytic developmental potential. 
Calcif Tissue Int 49: 221-225 1991.

3）水野守道, 久保木芳徳 : 骨芽細胞の分化におけ る Osteocalcin, Osteonectin, そして Osteopontin 遺伝子の発現について.日骨代謝 誌 10: 21-29 1992 .

4）野田政樹：TGF- $\beta$ ファミリーと骨代謝. 実験 医学 $8: 345-3501990$.

5）山口 朗, 池田 通, 他：骨芽細胞の培養. 組 穖培養 15: 155-159 1989 .

6）小野寺滋也, 角田左武郎, 他：骨芽細胞様細胞 のチタンプレートへの初期付着について. ロ科 誌 44: 160-165 1995.

7) Kodama, H., Amagi, Y., et al.: Establishment of a colonal osteogenic cell line from newbone mouse calvaria. Jpn J Oral Biol 23: 899-901 1981.

8) Sudo, H., Kodama, H., et al.: In vitro differentiation and calcification in a new clonal osteogenic cell line derived from newbone mouse calvaria. J Cell Biol 96: 191-198 1983.

9）稲用隆史 : チタンの放電加工に関する研究. 歯 科材料. 器械 $7: 606-6211988$.

10）鈴木利彦, 藤森伸也, 他：リン酸電解溶液中で のチタンの放電陽極酸化処理に関する研究. 昭 歯誌 12: 134-146 1992.

11) Zacharchuk, C.M., Drysdale, B., et al.: Macrophage-mediated cytotoxity: Role of a soluble macrophage cytotoxic factor similar to lymphotoxin and tumor necrosis factor. Proc Natl Acad Sci 80: 6341-6345 1983.

12) Chang, C., Gendler, E., et al.: Age dependence of bone matrix induced bone formation. Ornoy, A., Harell, A., et al.: Current advances in skeletogenesis. Elsevier Science Publishers, New York, 1985, P27-32.

13）代田達夫, 大野康亮, 他 : 加齢がヒドロキシア パタイトと骨との結合に及ほす影響について。 日口外誌 38: 41-47 1992.

14）腰原康子：ヒト骨芽細胞機能と老化. Gerontology $4: 413-4191992$.

15）角田左武郎, 濱崎美樹, 他：骨芽細胞様細胞の チタンプレートへの初期付着におよほす放射線 の影響. 口科誌 : 45: 136-142 1996.

16) Joyce, M.e., Roberts, A.B., et al.: Transforming growth factor- $\beta$ and the initiation of chondrogenesis and osteogenesis in the rat femur. J Biol Chem 110: 219522071990.

17) Noda, M. and Camilliere, J.J.: In vivo stimulation of bone formation by transforming growth factor- $\beta$. Endocrinology 124: 2991-2994 1989.

18) Tashjian, A.H., Voelkwl, E.F., et al.: $\alpha$ and $\beta$ Transforming growth factors stimulate prostagiandin production and bone resorption in cultured mouse calvaria. Medical Sciences 82: 4535-4538 1985.

19）竹内靖博, 福本誠二, 他: 骨芽細胞様 MC $3 \mathrm{~T} 3-$ E 1 細胞の分化に伴う TGF- $\beta$ 受容体および作 用発現の減少に対する Collagen の役割．日骨 代謝誌 12: 921994.

20）松本俊夫 : 骨代謝の調節機構と骨粗棇症の病態 生理に関する研究.日骨代謝誌 12:130-135 1994. 